Ann. Biol. anim., Bioch., Biophys., rg66, 6 (2) I59-I64.

\title{
LA CULTURE IN VITRO DE L'GEF DE VACHE
}

\author{
C. 'THIBALLT'

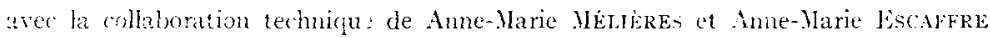 \\ Station centrale de Physiologie animale, \\ Centre national de Recherches zootechniques, 78-Jouy-en-Josas
}

Les études sur la fécondation et l'embryologie expérimentales des Mammifères sont rendues très difficiles par la localisation obligatoire des œufs en des parties précises des trompes ou de l'utérus. Seule, la connaissance de milieux de culture apporte la solution satisfaisante à l'expérimentateur, et les beaux travaux récents d'embryologie expérimentale chez la Souris (BRINSTER, I965; MINTZ, I965; MULNARD, I965; TARKOWSKI, I965) n'ont été rendus possibles que par la découverte par HAMMOND (I949), par WhiTTEN (I957), puis par BRINSTER (I963), de milieux permettant la segmentation normale de cet ouf in vitro jusqu'au stade préimplantatoire.

La possibilité de cultiver l'œuf des Ruminants offrirait, en outre, l'avantage d'une application éventuelle : des œufs tubaires fécondés, ou ovariens et fécondés in vitro, pourraient, après culture in vitro permettant leur contrôle et leur segmentation, être regreffés dans les cornes utérines de femelles nourrices.

Chez les Ruminants, seuls les cufs de Brebis et de Chèvres ont été cultivés jusqu'au stade blastocyste dans du sérum sanguin homologue (WINTENBERGER, Dauzier et ThibaulT, I953). Ians un tel milieu, l'œuf de Vache, au contraire, ne se divise jamais (PIncus, I95I ; HAFEz, Sugie et Gordon, I963).

Nous avons recherché un milieu permettant sa culture. Le liquide amniotique s'est révélé, même après chauffage à $58-60^{\circ} \mathrm{C}$ pendant 20 minutes, hautement toxique. L'analyse cytologique montre que la mort de l'œuf intervient en quelques heures.

Le liquide de Locke, le mélange de Locke et de sérum, l'humeur aqueuse, ne permettent également aucune segmentation.

Avec le sérum homologue, chauffé à $5^{\circ} \mathrm{C}$ pendant 20 à 30 minutes, nous n'avons que rarement observé des divisions régulières.

Au contraire, le liquide des follicules de de Graaf s'est révélé comme un bon milieu de culture permettant d'obtenir des clivages réguliers allant jusqu'à 24 blastomères; l'intégrité des structures cytoplasmiques et nucléaires et la présence de figures mitotiques confirment sa valeur. 


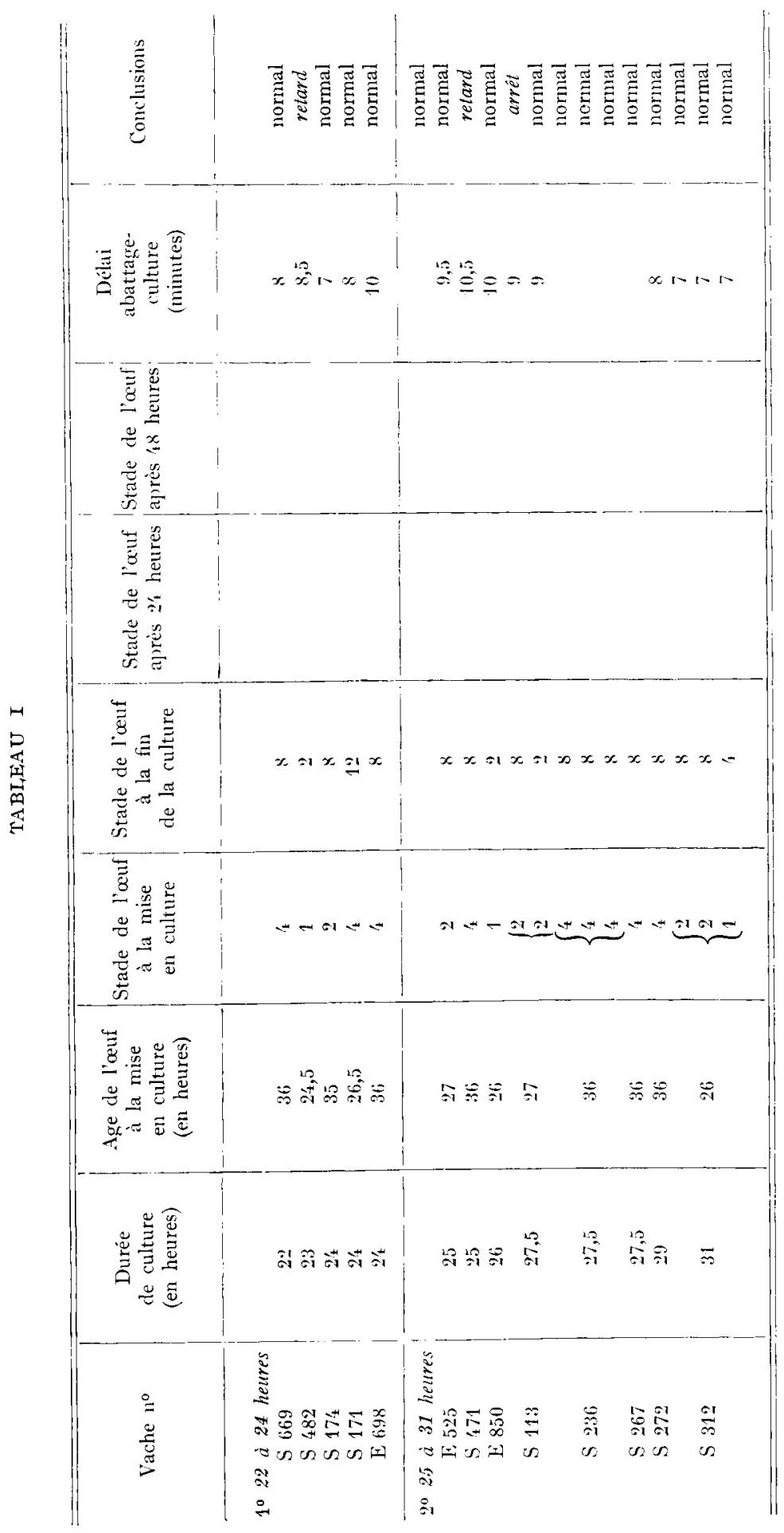


CUITURE " IN VITRO "DE L'OEUF DE VACHE

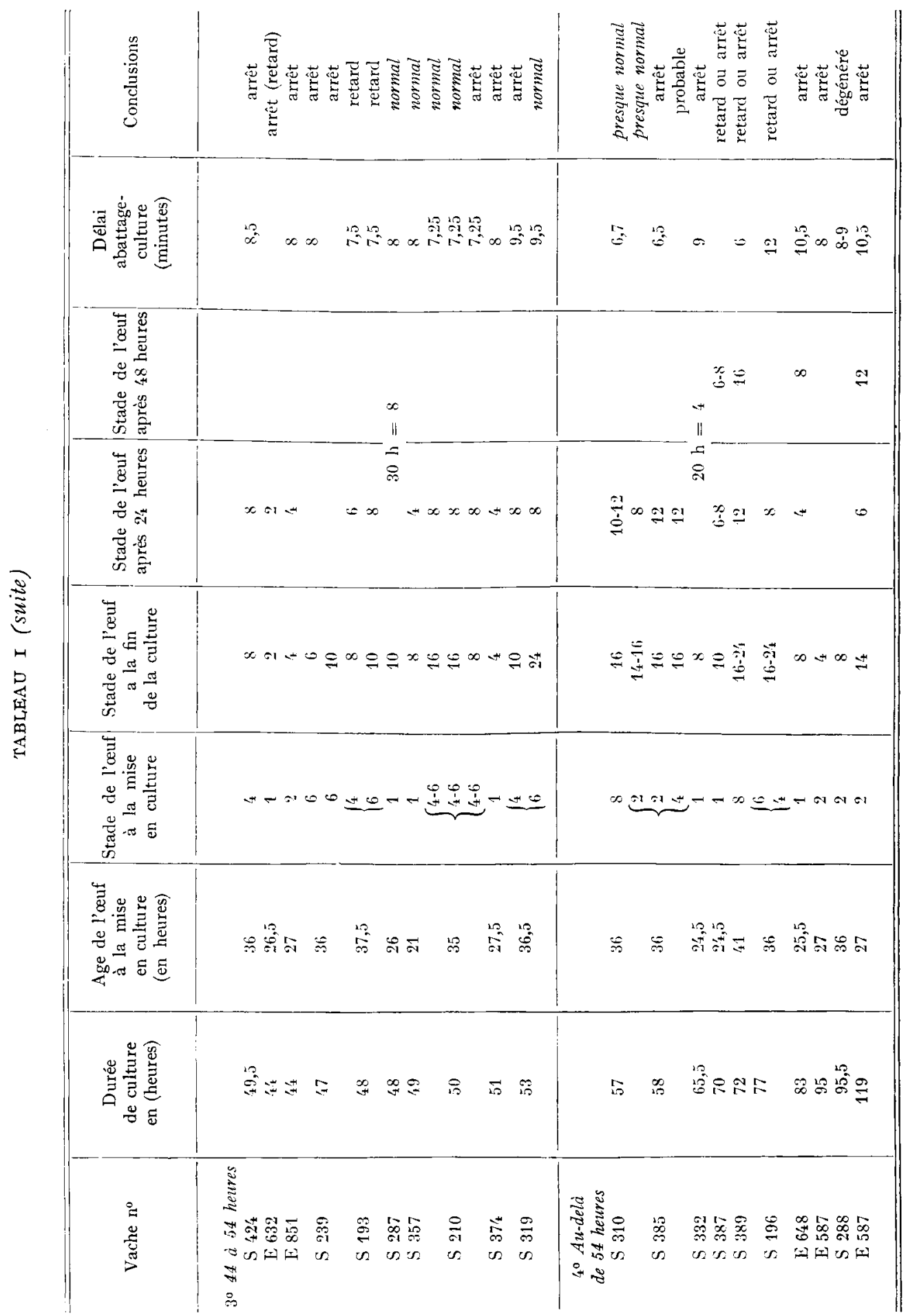


Le liquide folliculaire est prélevé aseptiquement sur des ovaires de Vaches ayant reçu, 60 heures avant, une injection intraveineuse de 7500 UI de PMS.

L,es cufs ont été recueillis, le plus souvent, de la façon suivante : l'animal aussitôt saigné est suspendu par le train postérieur et éviscéré, les trompes sont perfusées in situ de la corne utérine vers le pavillon avec du sérum homologue à $37^{\circ} \mathrm{C}$; le liquide de perfusion coulant du pavillon est collecté dans un verre de montre; les oufs sont recherchés et transportés immédiatement dans du liquide folliculaire. C'est le délai entre la mort de l'animal et le transfert des oufs dans le liquide folliculaire qui figure dans la colonne $S$ du tableau.

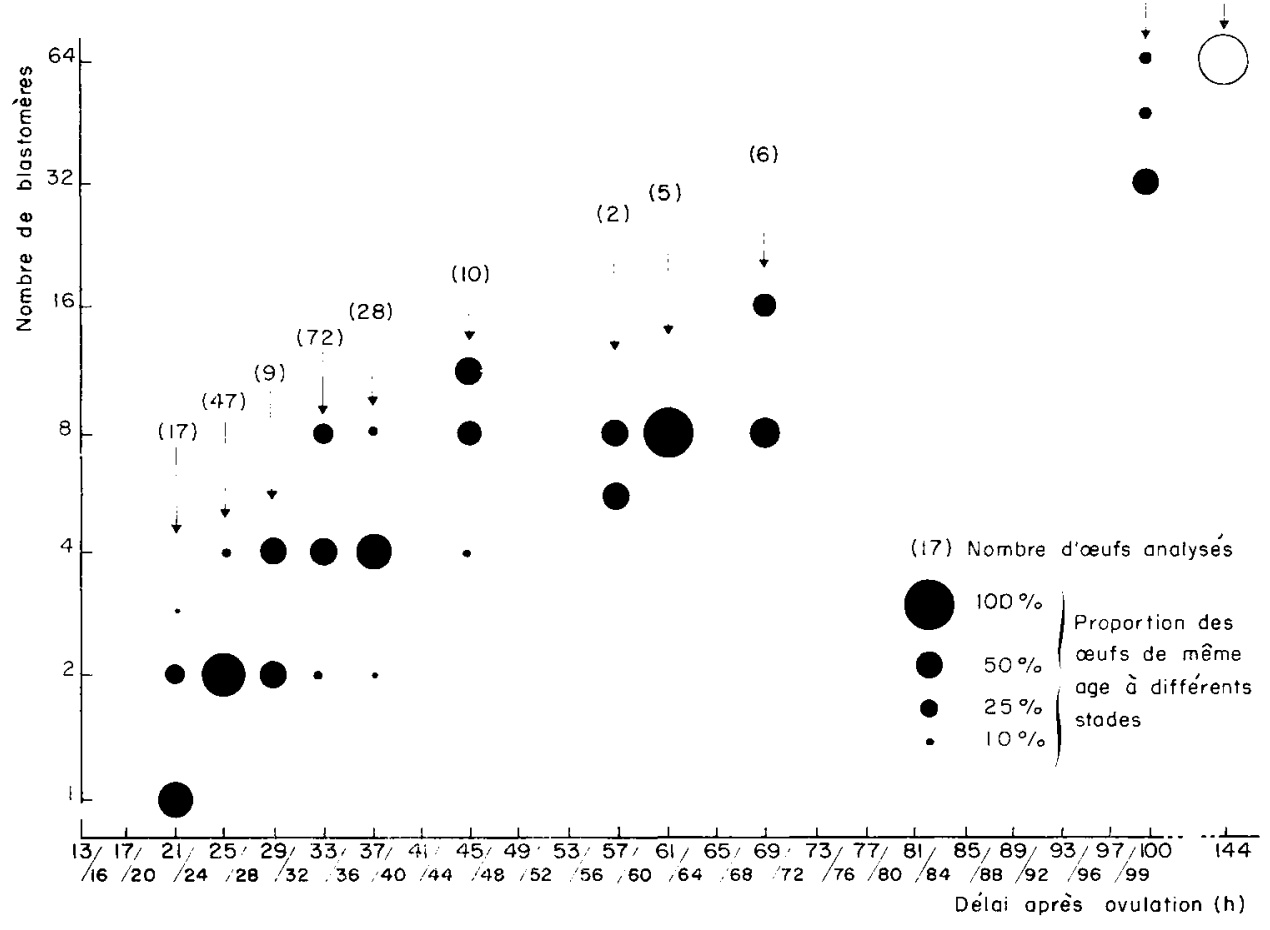

FrG I

La culture est effectuée dans des tubes de verre fermés aux deux extrémités par une goutte d'huile de paraffine et placés sur un rotor, tournant de façon discontinue (voir 'Thibauli et Dauzier, rg6r).

Tous les œufs ont été fixés, inclus, coupés à ro $\mu$, colorés et analysés par examen microscopique au $40 \times$ ou au roo $\times$ Planapochromat de Zeiss.

Pour reconnaître si la vitesse de segmentation était la même in vitro qu'in vivo, nous avons reporté sur un graphique les stades de segmentation observés à des délais croissants après l'ovulation (fig. I) de Vaches normales, accouplées; les valeurs obtenues sont conformes à celles publiées par Amoroso, Griffiths et Hamilton, (I942). 
Le tableau I groupe les résultats que nous avons obtenus avec des ceufs mis en culture r 2 minutes ou moins après la mise à mort de l'animal.

Ces résultats sont classés par durées de culture croissantes.

Tout d'abord, on doit remarquer que parmi les oufs non divisés au moment, de la mise en culture, 3 sur ro n'ont pas dépassé le stade 2 cellules (S 482, E 850 $\mathrm{E}$ 632). Il est possible que ces œufs aient déjà subi un retard dans leur développement avant la mise en culture (fécondation tardive, par exemple) ou que le stade 2-4 soit difficile à franchir in vitro.

Lorsque la durée de la culture est de 22 à 24 heures, la segmentation se poursuit d'une manière parfaitement normale, à l'exception d'un œuf ( $\mathrm{S} 482$ ) rentrant dans la catégorie ci-dessus.

Il en est de même si la durée de culture est comprise entre 27 et $3 \mathrm{I}$ heures. Un seul retard a été observé, il intéresse également un œuf non divisé au moment de la mise en culture ( $\mathrm{E}$ 850).

Pour des cultures de 44 à 54 heures, les arrêts sont fréquents au stałe 8 -Io, et seulement 5 œufs sur I5 ont continué à se diviser normalement is 287, S 357, S 2 Io et $\mathrm{S}$ 3 I 9 ).

Au-delà de 54 heures, tous les œufs ont subi un arrêt plus ou moins précoce de leurs divisions et aucun n'a dépassé le stade I6-24 blastomères.

L'œuf de Vache se comporte donc plus comme un cuf de Brebis que comme un ceuf de Souris, totalement incapable de franchir le stade 2 in vitro quel que soit le milieu, ou comme un œuf de Lapine, qui atteint in vitro le stade blastocyste sans difficulté.

Il nous apparaît donc nécessaire de procéder à des cultures d'œufs plus âgés à partir du stade I6 ou 24 blastomères pour voir si ces œufs sont capables alors, après avoir dépassé un stade critique comme les ceufs de Brebis, de se segmenter in vitro jusqu'à un stade avancé.

En résumé, dans le liquide folliculaire homologue, 1'œuf de Vache se divise régulièrement in vitro, au moins jusqu'au stade 8 -r2, le stade 24 cellules est parfois atteint, mais en l'état actuel de nos expériences, nous ne sommes pas parvenus à le dépasser.

Reçu pour publication en arril 1966.

\section{REIMERCIEMENTS}

Cette étude a été réalisée grâce à l'aide de la D. G. R. S. T. à qui nous exprimons nos remerciements. (contrat 63 FRO99)

\section{SUMMARY}

IN VITRO CULTIRE OF COW Ei;G

The lifuid from the large graafian follicles of cow ovary induced by PMS injection, revealed a medium suitable for in aitro segmentation of fertilized cow egg. This segmentation could not be obtained in other media.

The egg regularly cleaved up to the 8-12 cells stage, sometimes to $16-24$ cells stage, which in vivo is the stage when the egg shifts to the uterus. 


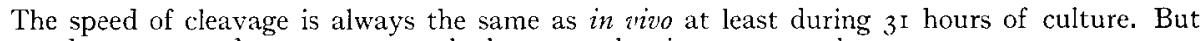
from 44 hours onwards, some eggs only keep on cleaving at normal rate.

The 24-cell stage was never passed beyond, even after i ig hours of culture.

\section{RÉFÉRENCES BIBLIOGRAPHIQUES}

Anoroso E. C., Grifitis W. F. B., IIAmilton W. J., 1942, The early development of the groat (Capra hircus). I. Anat., 76, 377-+06.

Brinster R. L., I963. A method for in vilto cultivation of Mouse ova from two cells to blastocyst. Exp. Cell Res., 32, $205^{-208 .}$

Brinster R. L., I965. Studies on the culture of Mouse ova. A Ciba Symposium on "Preimplantation stages of pregnancy i.

HAFEZ L. S. E., Scie 'T., GoRDon I., ro63. Superovulation and related phenomena in the beef Cow. I. Superovulatory responses following PMS and HCG injections. J. Reprod. Feritl., 5, 359-37\%.

Hammond J. jr, 1949. Recovery and culture of tubal Mouse ova. Nature, 163, 28.

Mintz B., I 965 . Nucleic acid and protein synthesis in the developing Mouse egs. A Ciba Symposium on "Preimplantation stages of pregnancy"

Iutanard J. G., ig65. Studies of regulation of House ova in vitro. A Ciba Symposium on "Preimplantation stages of pregnancy".

Pinces G., 1949. Observations on the development of Cow ova in vivo and in viliro. Proc. 1st Nat. Esg Transfer. Breet. Conf., San Intonia, Texas, I\$-2 I.

TARKowski A. K., 1965. Embryonic and postnatal development of Mouse chimeras. A Ciba Symposium on "Preimplaniation stages of pregnancy".

Thibault C., Dauzier L., Ig6r. Analyse des conditions de la fécondation in aitro de l'cuf de la Iatpine. Ann. Biol. anim. Bioch. Biophys., 1, 277-294.

WintTex W. K., 1956. Culture of tubal Mouse ova. Nalure, 17\%, 96.

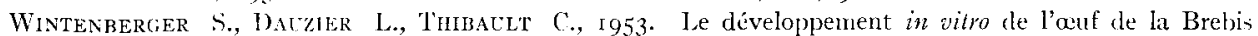
et de relui de la chevre. C. R. Soc. Biol., 147, 1971-1973. 